\title{
Potential expansion of rubber (Hevea brasiliensis Muell. Arg.) cultivation to the Northern region of Sri Lanka: SWOT analyses in Vavuniya district
}

\author{
V H L Rodrigo*, S M M Iqbal*, E S Munasinghe* and B M D C Balasooriya* \\ *Rubber Research Institute of Sri Lanka, Dartonfield, Agalawatta, Sri Lanka
}

Received 22 November 2012

\begin{abstract}
Rubber cultivation in Sri Lanka is in the expansion process to drier non-traditional areas to cater the demand. Having sufficient lands and then with additional objective of improving rural livelihood, Eastern and Northern region of Sri Lanka has been targeted for this expansion. With the initial success in the intermediate zone of Eastern province, rubber was introduced to the dry zone in Vavuniya district for the first time in 2010. However, no information was available on its potential expansion and factors to be considered. Therefore, this study was aimed to address this need through a detailed analysis on Strengths, Weaknesses, Opportunities and Threats (SWOT) for rubber cultivation in Vavuniya. Collection of secondary data and farmer workshops for SWOT analyses were tools of the study. Despite the availability of lands, farmers in Vavuniya - North had limited access to lands. Prospective stability in income was the opportunity expected by farmers from rubber cultivation. As a realistic target; cultivating 4,000 ha of rubber in Vavuniya district is proposed with the concept of "one family one hectare of rubber". Factors to be considered in allocating lands for rubber, a protocol for its expansion and needs for future studies are also discussed.
\end{abstract}

Key words: environment, land availability, non-traditional area, rubber forest, rural livelihood

\section{Introduction}

Although the demand for natural rubber based products is increasing, urbanization and industrialization prevent the expansion of rubber cultivation further in the traditional rubber growing wet zone (WZ). Nevertheless, more rubber has to be produced to cater the demand. With this background, the government of Sri Lanka (GoSL) has decided to expand rubber cultivation to drier nontraditional areas. In particular for this exercise, East and North regions of the country have been focused not only because their land per capita is

62 
reasonably higher, but also the livelihood of the people who were entangled in 30 year war, has to be upgraded. In this process, rubber was initially grown in the Intermediate Zone (IZ) of Eastern province and found successful in terms of both agronomic (Iqbal et al., 2010) and social aspects (Rodrigo et al., 2009, 2011a). With that privilege, GoSL suggested to expand rubber cultivation to the Dry zone (DZ) of East and North regions.

However being drier than IZ, agromanagement practices in DZ would be more critical than those in either $\mathrm{WZ}$ or IZ. As experienced in India, there may be a prolonged immature period and decline in yields (Datta et al., 2010). Water availability for irrigation is very limited in this region and where it is available, those lands are devoted for more remunerative short term cash crops (Rodrigo et al., 2009). Despite that it is expected to grow rubber under rain fed conditions, some are interested in growing rubber with some level of irrigation. Farmers' decision will depend on prevailing socio economic and cultural factors such as the cost involved and profitability, financial assets and priorities, labour availability, time lag between initial investment and returns, knowledge and cultural affinity. Accordingly, site/farmer specific variations will be resulted; however, general trend will be driven mainly by strengths and weaknesses pertaining to the rubber cultivation in the society. Farmers in the North were initially familiarized in rubber cultivation with few smallholder plots established in 2010 and 2011 in Vavuniya and Mulativu districts (Rodrigo et al., 2011b). Also, a set of recommendations for agronomic practices was issued (Rodrigo et al., 2011b). Nevertheless, no proper study has been undertaken to assess the potential for expansion of rubber cultivation in this region in terms of what farmers perceive. Such assessment is required before investing on any large scale programme on rubber cultivation. Therefore, the present study was aimed to do so with analyses on strengths, weaknesses, opportunities and threats (SWOT) for rubber cultivation in Vavuniya district.

\section{Material and Methods}

The study confined to Vavuniya district to where rubber was firstly introduced in the Northern Province and comprised two approaches, i.e. gathering information from secondary data available for this region and, undertaking a farmer participatory rural appraisal (PRA) on strengths, weaknesses, opportunities and threats (SWOT analysis) for rubber cultivation in the area.

Information available at the District Secretariat Vavuniya and the Department of Census and Statistics on general statistics such as population density, land availability and farmers' livelihood, and agro-specific features such as soil type, rainfall and ground water availability in the area was gathered. Farmer workshops were organized for the SWOT analyses with 
farmers' view on rubber cultivation in the areas coming under two Divisional Secretariats, namely Vavuniya - South (V. South) and Vavuniya - North (V. North) where farmers had some experience on rubber planting due to the smallholder rubber lands established. Each area had a separate SWOT analysis and, farmers who had already planted and who showed some interest to plant rubber participated in these workshops together with their neighbors. In Vavuniya - South, 20 farmers participated in the workshop whilst there were 32 participants in Vavuniya - North.

At the beginning of the workshop, general information useful to assess the potential for rubber cultivation such as livelihood strategies and income levels, number of family members, land availability, crops cultivated, soil water availability and social organizations was collected in group wise.

SWOT analysis began with 'Strengths' and followed by Weaknesses, Opportunities and Threats. Farmers were initially guided showing what scientists perceived under each category with the help of a flipchart and then encouraged to build up an own list. Thereafter, farmers were guided to rank the items under each category based on the importance as they perceived. In instances where a common consensus could not be obtained, the decision on the ranking position was taken considering the preference of the majority. Once the ranking had been completed, the ranking positions were quantified with marks given by the farmers. In this process, 100 marks were given to the top and then the marks for the rest under each category were determined by the farmers considering the relative importance. When farmers proposed different levels of marks for an item, the average of those values was taken.

In each community, relative distribution of each item under four different categories of SWOT was also assessed. To do so, each farmer was categorized (as per the general perception of farmers) under three levels, viz. high, medium and low, for each item in the list and then percentage values for each level calculated. Whilst distinct levels could be used for the categorization of land and labour availability, grouping procedure of other factors was rather location specific. In land availability, low, medium and high categories referred to the farmers having less than 1ha, 1-2 ha and above 2 ha, respectively. Low, medium and high categories in family labour availability were denoted respectively when number of members available is zero or one, two and three or above. At the end of the SWOT analyses, farmers collectively mentioned their immediate needs for successful cultivation of rubber. 


\section{Results}

General information gathered from secondary data;

According to the average monthly distribution of rainfall for the period of 1999- 2008, Vavuniya receives rains mostly during October to December and that covers $51 \%$ of the annual total (Fig. 1). In late September, rainy season starts and then ends by early February. Despite some rains in April, other months are fairly dry with no rains received in some years. Total land area in both V. South and V. North is over 98,190 ha (Table 1). In total, there are 197 villages in 40 Grama Niladari divisions. The population of both divisions is 24,588 in 8,917 families. With that, the average number of persons in a family is about 3 . Also, no serious deviation in gender balance was observed.

Table 1. Demographics in Vavuniya district

\begin{tabular}{lll}
\hline Details & Vavuniya South & Vavuniya North \\
\hline Total land area (ha)*1 & 23,590 & 74,600 \\
Gramasevaka divisions (GS)*1 & 20 & 20 \\
Villages $^{* 1}$ & 91 & 106 \\
Population $^{*^{2}}$ & 13,070 & 11,518 \\
Gender ratio (male:female) $^{* 2}$ & .98 & 1.09 \\
Families*1 $^{*}$ & 4,711 & 4,206 \\
Average land (ha)/family*3 & $1-2 \mathrm{ac}$ & $1-2 \mathrm{ac}$ \\
\hline
\end{tabular}

Sources: $*^{1}$ (Anon, 2010), $*^{2}$ (Anon, 2012b), $*^{3}$ (Anon, 2009)

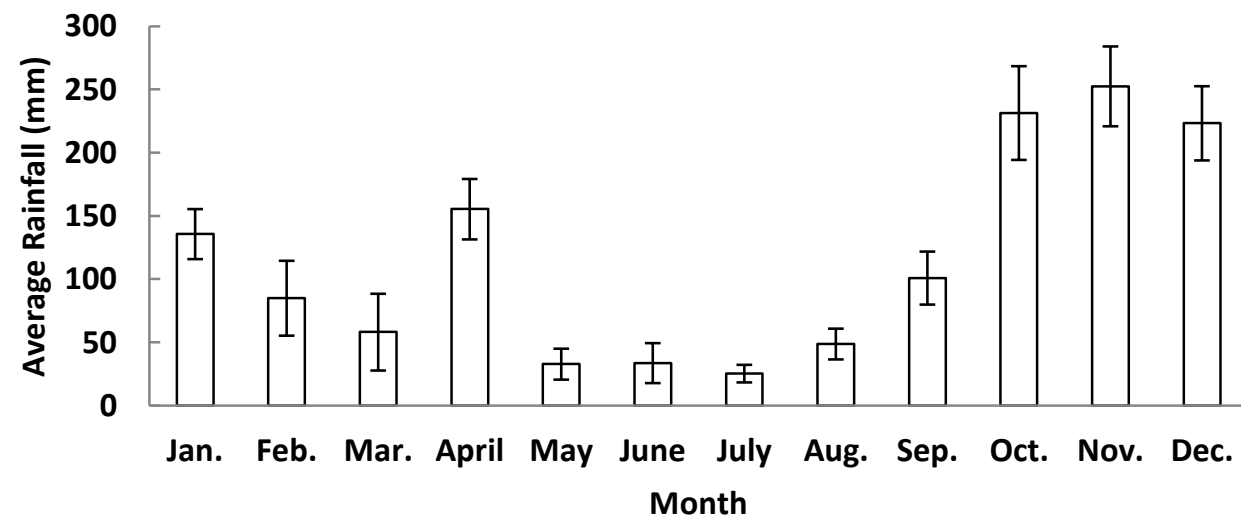

Fig. 1. Monthly distribution of rainfall in Vavuniya. Each value represents the mean rainfall for last 10 years with error bars for the standard error of means. Source: (Anon, 2009) 
Sparsely cultivated chena lands have been the biggest component in agriculture (Table 2). Lands devoted for paddy cultivation secured the second place in agriculture in both DS divisions. Also on average, $19 \%$ of agricultural lands has been allocated to homesteads. Natural forests covered a large area of lands $(53,510 \mathrm{ha})$, particularly in V. North $(48,000$ ha). Total area under forest plantations was only 140 ha. However, lands under shrubs have spread over 9,190 ha in both DS divisions with the majority in V. North. There is a large area under water bodies (4,340 ha) and that was $35 \%$ higher in V. South than in V. North.

Table 2. Land use for agriculture and forestry in Vavuniya

\begin{tabular}{|c|c|c|c|c|}
\hline \multirow{2}{*}{\multicolumn{3}{|c|}{ Land use pattern }} & \multicolumn{2}{|c|}{ Extent (ha) } \\
\hline & & & $\begin{array}{l}\text { Vavuniya } \\
\text { South } \\
\end{array}$ & $\begin{array}{l}\text { Vavuniya } \\
\text { North } \\
\end{array}$ \\
\hline \multirow{4}{*}{$\begin{array}{l}\text { Agricultural } \\
\text { land }\end{array}$} & \multicolumn{2}{|l|}{ Homesteads } & 2,730 & 3,140 \\
\hline & \multirow{3}{*}{ Crop lands } & Paddy & 4,470 & 3,690 \\
\hline & & $\begin{array}{l}\text { Sparsely cultivated } \\
\text { lands }\end{array}$ & 5,220 & 11,160 \\
\hline & & Other crop land & 160 & - \\
\hline \multirow{4}{*}{ Forest land } & \multirow{3}{*}{ Natural } & Dense forest & 4,890 & 19,816 \\
\hline & & Open forest & 620 & 2,280 \\
\hline & & Reserved for forests & - & 25,904 \\
\hline & \multicolumn{2}{|c|}{ Forest plantations } & 20 & 120 \\
\hline \multirow{2}{*}{ Range land } & \multicolumn{2}{|l|}{ Scrub land } & 2,630 & 6,560 \\
\hline & \multicolumn{2}{|l|}{ Grass land } & 130 & 40 \\
\hline \multirow{2}{*}{ Wet land } & \multicolumn{2}{|l|}{ Water bodies } & 2,500 & 1,840 \\
\hline & Non forested & Marsh & 170 & 50 \\
\hline \multicolumn{3}{|l|}{ Barren land } & 10 & - \\
\hline \multicolumn{3}{|l|}{ Other } & - & - \\
\hline \multicolumn{3}{|l|}{ Total } & 23,590 & 74,600 \\
\hline
\end{tabular}

Source: (Anon, 2012)

$\overline{66}$ 
Information from farmer participatory workshops;

In both North and South divisions of Vavuniya, the majority of farmers was engaged in farming as the main occupation and then in state security services (Table 3). Average number of members in a family was alike in both divisions. However, there were $18 \%$ of households having over 5 members in V. North though not a single family in V. South was found to be in this category (Fig. 2a). The availability of family labour in V. South was higher than that in V. North (Fig. 2b). In particular, there were $34 \%$ families in V. North that cannot allocate any member of the family for farming. However in V. South, each family was able to devote at least a member for farm activities (Fig. 2b). Participants in V. South were generally in high income categories. Whilst $45 \%$ of this region has an income above Rs.15,000/= per month, there was not a single one in V. North in this category (Fig. 3). Also, there was no one below Rs.5,000/= per month in V. South. In V. North, all families fell below Rs.10,000/= per month and $23.5 \%$ of them were in the category of below Rs.5,000/=. In both divisions, the majority of farmers had lands between $0.4-1$ ha (1-2.5 acres); however, there were $45 \%$ participants in V. South with over 1 ha (Fig. 4a). Also, $15 \%$ of participants in V. South had even over 2 ha whilst no participants in $\mathrm{V}$. North were found in this category. Only $22 \%$ of participants were willing to cultivate rubber in $\mathrm{V}$. North and the majority could allocate only 0.2 ha $(0.5$ Ac) (Fig. 4b). In contrast, $75 \%$ of participants in V. South wished to plant rubber with the majority falling into 0.40.8 ha (1-2 Ac). As seasonal crops, maize, cowpea, green gram, black gram, ground nuts and chillies were grown by all participants in V. South and rice, brinjol and red onion by those in $\mathrm{V}$. North (Table 4). In addition, tobacco, banana and cassava were also grown by the majority in V. North. Coconut, jack and mango were grown as permanent crops in home gardens in both divisions. In addition, rice, banana, cashew and teak were grown in V. South.

Rural Development Society and women's societies on agriculture were attended by the farmers in both divisions. Sewa Lanka and CARE International were the voluntary organizations in V. North whilst Sarvodaya and Regaining Sri Lanka were functioning in V. South.

Table 3. Principal livelihood strategies in Vavuniya district

\begin{tabular}{lcc}
\hline Occupation & \multicolumn{2}{c}{ \% No. of families } \\
\cline { 2 - 3 } & V. South & V. North \\
\hline Farming & 90 & 78 \\
State security services & 10 & 22 \\
\hline
\end{tabular}


Rubber cultivation in dry climates

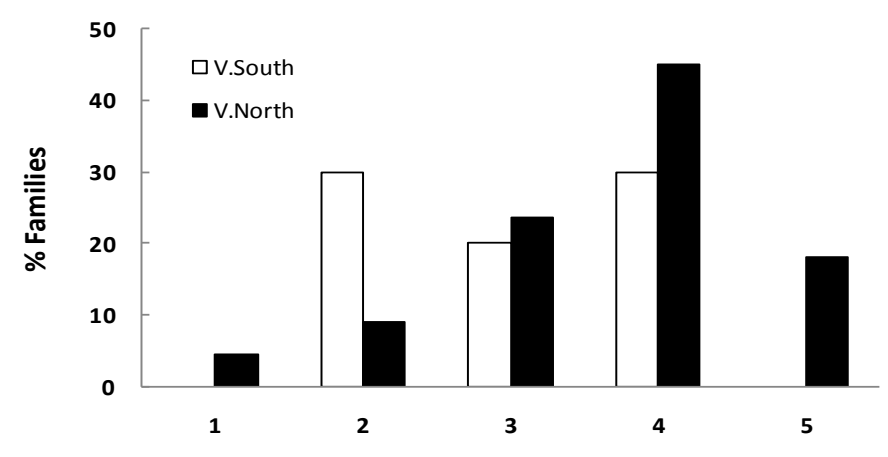

Number of family members

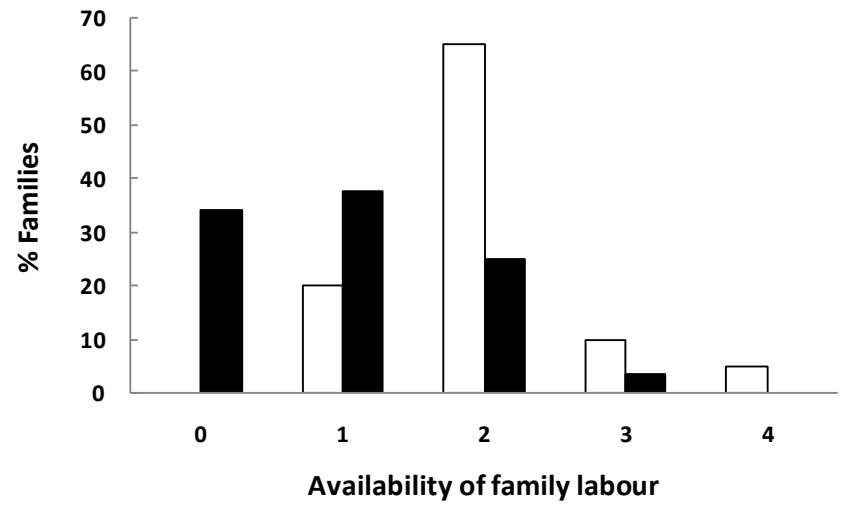

Fig. 2. Distribution of (a) family size and (b) availability of family labour in Vavuniya district

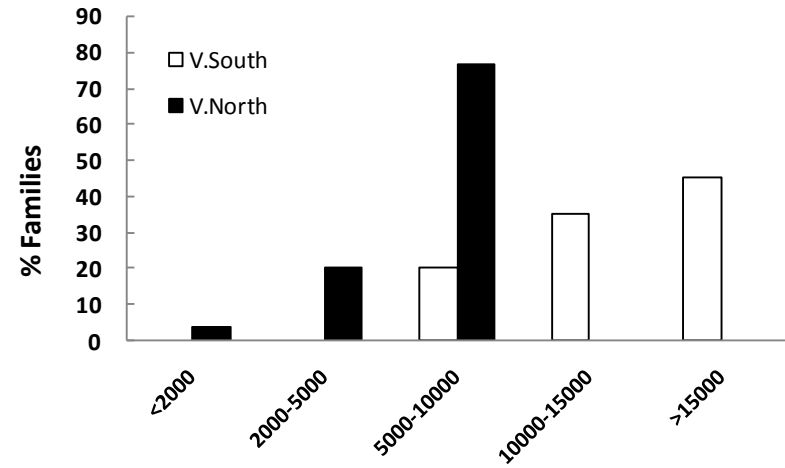

Monthly income (Rs.)

Fig. 3. Family income distribution in Vavuniya district

$\overline{68}$ 

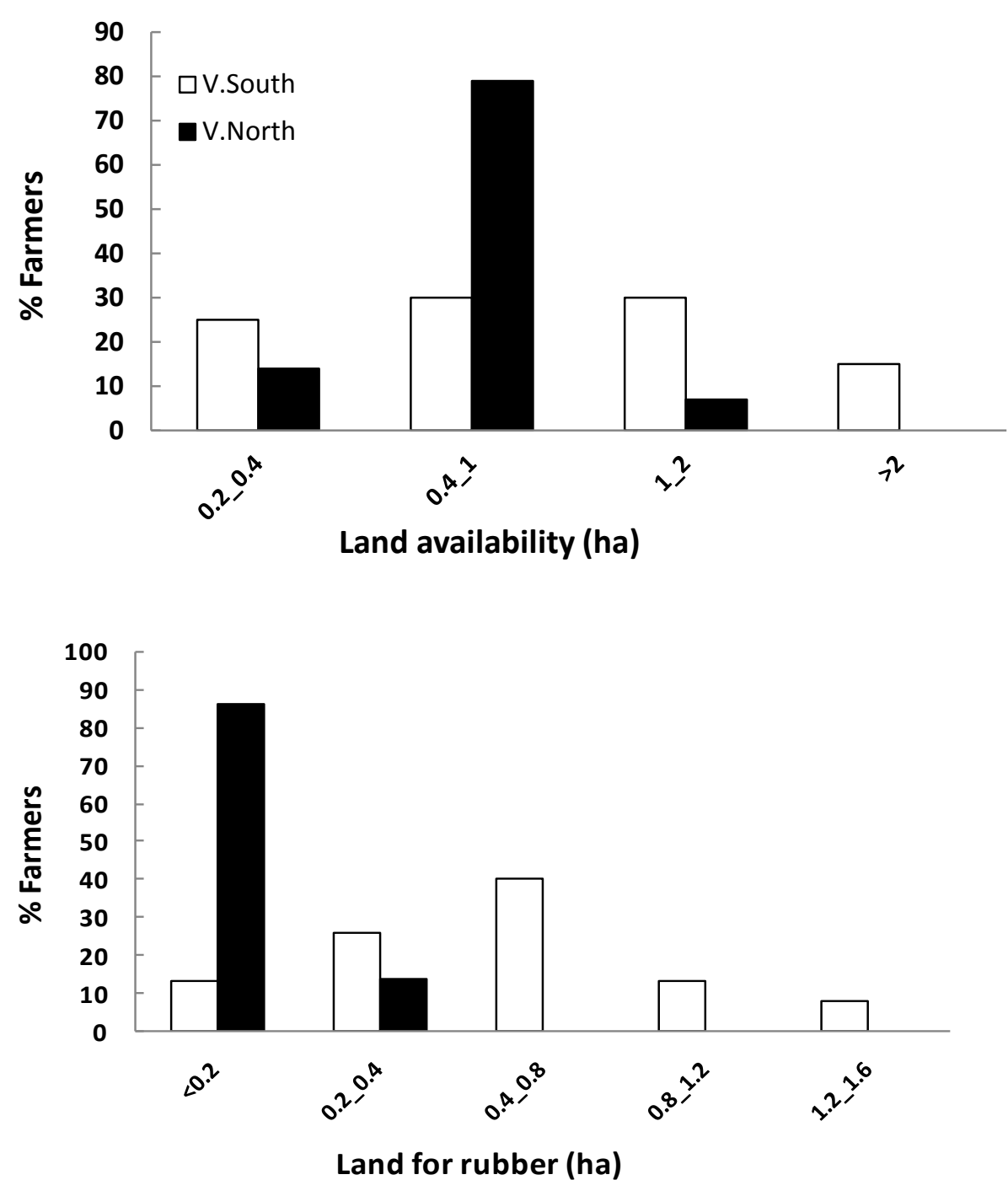

Fig. 4. Distribution of (a) the overall land availability and (b) land availability to rubber cultivation in Vavuniya district 
Rubber cultivation in dry climates

Table 4 Main crops cultivated in Vavuniya district

\begin{tabular}{lll}
\hline Crops cultivated & \multicolumn{2}{c}{ \% No. of families engaged in } \\
\cline { 2 - 3 } & V.South & V. North \\
\hline Maize & 100 & - \\
Cow pea & 100 & - \\
Green gram & 100 & - \\
Black gram & 100 & - \\
Ground nut & 100 & - \\
Chillies & 100 & - \\
Paddy & 70 & 100 \\
Tobacco & - & 50 \\
Red onion & - & 100 \\
Brinjal & - & 100 \\
Cassava & - & 70 \\
Banana & 65 & 78 \\
Coconut & 100 & 100 \\
Jak & 100 & 80 \\
Mango & 100 & 80 \\
Cashew & 100 & - \\
Teak & 30 & - \\
\hline
\end{tabular}

According to the farmers in both divisions, severe drought prevails in July-August and ground water goes down to the level of $7.5 \mathrm{~m}$ depth during this period. Agro-well were generally used for cultivation purposes in both Maha and Yala seasons. There has been a government subsidy programme to support the construction of agro-well with the provision of Rs.40,000/= per well. According to farmers, this covers about $25 \%$ of the total cost.

Despite of similar set of strengths, their ranking order was quite different in $\mathrm{V}$. North and V. South (Table 5). Land availability, interest to grow rubber and provision to supply water were the first three strengths for the rubber cultivation in V. South whilst family relationships, experience in farming and fertile soils were ranked top in the list in V. North. Land availability in V. South was the top in strengths with $30 \%$ and $15 \%$ farmers were fallen into the middle and high categories, respectively. In V. North, farmers perceived to keep the land availability at $6^{\text {th }}$ place with no one in high category. Interest to grow rubber was at the least important strength in $\mathrm{V}$. North though it secured the second place in V. South. Similarly, soil fertility and experience in farming were at the bottom of the list in V. South and it was vice versa in V. North. Availability of finance for initial investment has not been a strength in $\mathrm{V}$. North. 
V H L Rodrigo et al.

Table 5. Relative distribution and scores of the strengths for rubber cultivation in Vavuniya district (A score of 100 was given to the topmost item and others have been valued considering the relative importance)

\begin{tabular}{|c|c|c|c|c|c|c|c|c|}
\hline \multirow[t]{3}{*}{ Strengths } & \multicolumn{4}{|c|}{ V.South } & \multicolumn{4}{|c|}{ V. North } \\
\hline & \multicolumn{3}{|c|}{$\begin{array}{c}\text { Relative distribution } \\
(\%)\end{array}$} & \multirow[t]{2}{*}{$\begin{array}{c}\text { Rank } \\
\text { (Score) }\end{array}$} & \multicolumn{3}{|c|}{$\begin{array}{c}\text { Relative distribution } \\
(\%)\end{array}$} & \multirow[t]{2}{*}{$\begin{array}{l}\text { Rank } \\
\text { (Score) }\end{array}$} \\
\hline & High & Medium & Low & & High & Medium & Low & \\
\hline $\begin{array}{l}\text { Land } \\
\text { availability }\end{array}$ & 15 & 30 & 55 & $1(100)$ & - & 7 & 93 & $6(40)$ \\
\hline $\begin{array}{l}\text { Interest to } \\
\text { grow rubber }\end{array}$ & 100 & - & - & $2(90)$ & 16 & 7 & 77 & $7(35)$ \\
\hline Fertile soils & 100 & - & - & $7(40)$ & 48 & 39 & 13 & $3(70)$ \\
\hline $\begin{array}{l}\text { Experience in } \\
\text { farming }\end{array}$ & 100 & - & - & $7(40)$ & 48 & 32 & 20 & $2(85)$ \\
\hline $\begin{array}{l}\text { Labour } \\
\text { availability }\end{array}$ & 15 & 65 & 20 & $6(45)$ & 22 & 39 & 39 & $4(65)$ \\
\hline $\begin{array}{l}\text { Family } \\
\text { relationships }\end{array}$ & 100 & - & - & $6(45)$ & 51 & 13 & 36 & $1(100)$ \\
\hline $\begin{array}{l}\text { Agrarian } \\
\text { services }\end{array}$ & 100 & - & - & $5(50)$ & 26 & 58 & 16 & $5(50)$ \\
\hline $\begin{array}{l}\text { Provision to } \\
\text { supply water }\end{array}$ & 55 & 45 & - & $3(75)$ & 39 & 39 & 22 & $4(65)$ \\
\hline $\begin{array}{l}\text { Availability of } \\
\text { finance }\end{array}$ & 40 & 35 & 25 & $4(60)$ & - & - & - & $6(40)$ \\
\hline
\end{tabular}

The few weaknesses were reported. Lack of knowledge, droughts and fluctuations in labour demand were common to both V. North and V. South (Table 6). In addition, no local marketing systems for rubber latex and lack of apparatus for raw rubber processing were reported as weaknesses in V. South. Nevertheless, most participants in V. South perceived to be in low categories of weaknesses although the situation in V. North was vice versa. Farmers in both divisions perceived to have three opportunities, i.e. stable income from rubber, new income avenues and possibility to obtain subsidy payments for rubber, with same order of ranking (Table 7). Under the category of threats, droughts, cyclones and wild animal damages were reported (Table 8). In V. North, the damage by wild animals like elephants was the top in the list and the most participants were in high risk category. Although droughts secured the third place, participants fell mostly in middle and high categories. In V. South, farmers perceived to keep droughts at the top place in threats and then the wild animals. However, the level of importance in all threats in V. South was low. 
Rubber cultivation in dry climates

Table 6. Relative distribution and scores of the weaknesses for rubber cultivation in Vavuniya district (A score of 100 was given to the topmost item and others have been valued considering the relative importance)

\begin{tabular}{|c|c|c|c|c|c|c|c|c|}
\hline \multirow[t]{3}{*}{ Weaknesses } & \multicolumn{4}{|c|}{ V.South } & \multicolumn{4}{|c|}{$\begin{array}{r}\text { V. North } \\
\end{array}$} \\
\hline & \multicolumn{3}{|c|}{ \% Distribution } & \multirow{2}{*}{$\begin{array}{l}\text { Rank } \\
\text { (Score) }\end{array}$} & \multicolumn{2}{|c|}{$\%$ Distribution } & & \multirow{2}{*}{$\begin{array}{l}\text { Rank } \\
\text { (Score) }\end{array}$} \\
\hline & High & Medium & Low & & High & Medium & Low & \\
\hline $\begin{array}{l}\text { Lack of } \\
\text { knowledge }\end{array}$ & - & - & 100 & $1(100)$ & 48 & 26 & 26 & $2(85)$ \\
\hline Dry periods & - & 80 & 20 & $2(85)$ & 55 & 32 & 13 & $1(100)$ \\
\hline $\begin{array}{l}\text { Fluctuations in } \\
\text { labour demand }\end{array}$ & - & - & 100 & $3(65)$ & 32 & 39 & 29 & $3(70)$ \\
\hline $\begin{array}{l}\text { No local } \\
\text { marketing } \\
\text { systems for } \\
\text { latex }\end{array}$ & 5 & - & 95 & $4(45)$ & 13 & 32 & 55 & $4(40)$ \\
\hline $\begin{array}{l}\text { lack apparatus } \\
\text { for raw rubber } \\
\text { processing }\end{array}$ & 5 & - & 95 & $4(45)$ & - & - & - & - \\
\hline
\end{tabular}

Table 7. Relative distribution and scores of the opportunities for rubber cultivation in Vavuniya district (A score of 100 was given to the topmost item and others have been valued considering the relative importance)

\begin{tabular}{|c|c|c|c|c|c|c|c|c|}
\hline \multirow[t]{3}{*}{ Opportunities } & \multicolumn{4}{|c|}{ V.South } & \multicolumn{4}{|c|}{ V. North } \\
\hline & \multicolumn{3}{|c|}{$\%$ Distribution } & \multirow{2}{*}{$\begin{array}{l}\text { Rank } \\
\text { (Score) }\end{array}$} & \multicolumn{3}{|c|}{$\%$ Distribution } & \multirow{2}{*}{$\begin{array}{l}\text { Rank } \\
\text { (Score) }\end{array}$} \\
\hline & High & Medium & Low & & High & Medium & Low & \\
\hline Stable income & 100 & - & - & $1(100)$ & 52 & 35 & 13 & $1(100)$ \\
\hline $\begin{array}{l}\text { New income } \\
\text { avenues }\end{array}$ & 100 & - & - & $2(80)$ & 61 & 32 & 7 & $2(75)$ \\
\hline $\begin{array}{l}\text { Possibility to } \\
\text { obtain the } \\
\text { subsidy } \\
\text { payments }\end{array}$ & 10 & 90 & - & $3(40)$ & 42 & 58 & - & $3(55)$ \\
\hline
\end{tabular}


V H L Rodrigo et al.

Table 8. Relative distribution and scores of the threats for rubber cultivation in Vavuniya district (A score of 100 was given to the topmost item and others have been valued considering the relative importance)

\begin{tabular}{llllllll}
\hline \multirow{2}{*}{ Threats } & \multicolumn{3}{c}{ V. South } & \multicolumn{3}{c}{ V. North } \\
\cline { 2 - 8 } & \% Distribution & & $\begin{array}{l}\text { Rank } \\
\text { (Score) }\end{array}$ & \% Distribution & \multicolumn{1}{c}{$\begin{array}{l}\text { Rank } \\
\text { (Score) }\end{array}$} \\
\cline { 2 - 8 } & High & Medium & Low & & High & Medium & Low \\
\hline $\begin{array}{l}\text { Expected } \\
\text { droughts }\end{array}$ & & 100 & $1(100)$ & 42 & 35 & 23 & $3(55)$ \\
$\begin{array}{l}\text { Cyclones } \\
\begin{array}{l}\text { Wild animal } \\
\text { damages }\end{array}\end{array}$ & & 100 & $3(10)$ & 64 & 26 & 10 & $2(60)$ \\
\hline
\end{tabular}

\section{Discussion}

Rubber cultivation in the Northern Province was initiated in 2010 with planting rubber predominantly in the areas under V. South and V. North Divisional Secretariats in Vavuniya district (Rodrigo et al., 2011b). Land and ground water availability had been the principal criteria in the initial area selection and the present study confirmed availability of lands for such activities. Also, water is available even during dry periods in agro-wells. Despite the fact that most of the lands in these areas are covered by some form of forests, a large space has already been assigned for agriculture. According to the statistics of Provincial Information of Northern Province (Anon, 2012), 30,570 ha in total are cultivated in both V. South and V. North.

Farmers in V. South claimed the availability of lands as the top most strength whilst it was vice versa in $\mathrm{V}$. North. Nevertheless, with lesser population and greater land area devoted for upland cultivation in $\mathrm{V}$.
North, land per capita should be higher in this zone. Also, farmers in V. North showed less interest to rubber cultivation and had no initial capital to such activity. Though had to be entangled conflicts, people in V. South were free to visit rest of the island and it was not the case for the people in V. North. Not having opportunity to see the economic benefits, farmers in V. North would have expressed the less interest to plant rubber and thereby, unwillingness to devote the lands available for rubber. Nevertheless, lands availability per household in V. North (as farmers expressed) was mostly in the range of 0.4-1 ha. With given priority for seasonal crops, therefore, no additional lands for cultivation plantation crops like rubber in this region. In V. South, no such limitation was obvious and for instance, there were three farmers who have already grown rubber in over 3 ha. Land availability of two of them has exceeded 20 ha. Most lands available in V. South have been state owned and farmers have 
been issued land permits by the Divisional Secretariats for cultivation purpose. Such farmers did not carry proper deeds to claim outright land ownership but have more lands for farming. Therefore, actual land availability for cultivation in V. South appeared to be higher. In contrast, because of being highly entangled in the LTTE conflict, farmers in V. North would had not been allowed to do farming on state owned lands on security reasons and so, have only limited access to the lands though the land availability in the area is higher.

Despite the greater number of family members in V. North, their availability for farming has been less in this region than in V. South. People in V. North are in the process of resettling after the conflict and so, suffer from shortage of capital for investment (N.B. availability of financial capital was not strength in V. North). Hence, emigrant workers are present in families for better income from outside. This would have been the reason for less availability of family labour for farming in V. North. Such emigration would results in interfamily relationships among who reside in the village. Common suffering during the conflict period would have also led to strong interfamily relationship and so, farmers may have ranked this factor as the most important strength in V. North. Nevertheless, the relative position of labour availability in the list of strengths has been stronger in V. North than in V. South and, this was due the relative importance of other factors.
Water availability is an essential component in farming in the dry zone and most farmers have had agro-wells and solar driven water pumps for irrigation. Farmers have been provided subsidized schemes for building up agro-wells and purchasing such water pumps and so, availability water sources were ranked as $3^{\text {rd }}$ and $4^{\text {th }}$ position in the list of strengths for V. South and V. North. Further, government intervention in terms of mobilizing more resources to promote farming would have driven the people to rank agrarian services as a strength securing the fifth place both in V. South and V. North. Farmers in both divisions perceived that soil fertility has also been strength although its relative position in the list of strengths differs.

The majority of people in the area were farmers whilst a few engaged in security services. With the post-conflict development activities in the area, there have been some drives creating other job opportunities in future. According to the villagers, only few people engaged in such activities at present. People working for security services were also engaged in farming during offdays/hours and so, any improvement in farming systems may also apply for them.

As recorded under opportunities, income stability appeared to be the main objective of farmers in cultivating rubber. Also, farmers were interested in other income avenues to be generated along with rubber cultivation. These factors indicate the uncertainty of farmers' livelihood with traditional 
seasonal crops. Being mostly surrounded by forests, potential damage from wild animal damage was recorded as the top of the threats by the farmers in $\mathrm{V}$. North. Other threats were not much in concern. Farmers in V. South appeared to have had no worries on the threats recorded with all of them in low category.

Though not important at the initial stage, farmers showed their concern on latex processing and marketing system for rubber produced. Farmers were totally unaware the simple protocols for rubber sheet production and their long shelf-life which facilitates bulk marketing at farmers' wish. Lack of knowledge on rubber was a dominant factor and that would be the reason for farmers to express their concern on above factors.

As expected at the introduction of rubber to Vavuniya district, land availability would not be a limiting factor for rubber cultivation. Most lands belong to the government and so, a proper system should be derived in allocating them for rubber cultivation. No damage to natural forests, assigning lands to the land poor and people who have already grown crops on those lands, suitability for rubber and lands for other crops are to be the factors under consideration. In particular, farmers in Vavuniya contribute immensely to the food production in the country and so, it should not be threatened by rubber cultivation. Growing food crops with rubber is always encouraged during the immature phase of rubber as intercropping systems; nevertheless once rubber plants come to maturity, intercropping is limited to only few shade loving crops. Therefore, it is proposed to limit the rubber cultivation to one hectare per family and such extent is sufficient to provide a reasonable income per family, i.e. over Rs.40,000 per month (Rodrigo et al., 2009). There have been about 16,380 ha of sparsely cultivated lands which could be utilized for rubber. However, some areas would be unsuitable for rubber cultivation. Also leaving some lands for other crops, only $25 \%$ of the above extent $(4,000 \mathrm{ha})$ is proposed for rubber cultivation in Vavuniya district. Further, a part of some homesteads could also be used for rubber depending on farmers' will. However considering all above facts, 4,000 ha could be considered as a realistic target for rubber cultivation in this region. For the smallholder sector, it could be promoted with the theme of "one family one hectare of rubber" as a rural livelihood development programme. In addition, there is a large extent of lands reserved for aforestation. Rubber could be used as a multipurpose forest species to raise forest providing additional income to the country. Quick disbursement rubber subsidy to farmers would be required to address the problems of lacking the initial capital and effective technology transfer systems to upgrade their knowledge. At present, establishment of demonstration plots is underway in Northern region with Sri Lankan army. Usage of 
machineries for digging planting holes will facilitate on-time planting with the onset of North-East monsoon by addressing the issue of hard nature of soil before the rain (difficult for digging) and heavy demand for labour during this period. Particularly in forest boundaries, measures to prevent wild animal damage are required. In research, quantification of water requirement particularly during drought periods, anthropological studies to find hindering factors in the motivation of farmers for rubber planting and risk factor analyses would be in high priority in promoting rubber in the Northern region. Also, similar SWOT analyses are warrant for other potential districts for rubber cultivation in North, i.e. Mullativu and Killinochchi.

\section{Conclusions}

Despite the high land per capita in Vavuniya district, farmers in Vavuniya North have had limited access to land. However, that was not the case in the Vavuniya South.

Whilst farmers in Vavuniya South were highly interested in cultivating rubber, farmers in Vavuniya North were unwilling to do so.

Lack of knowledge and dry spells were found to be the top most weaknesses for rubber cultivation in the region.

Farmers in Vavuniya North suffered from shortage of financial capital. This appeared to be a hindrance to invest on long term crops like rubber. Also, it may have caused to mobilize family labour in off-farm activities.
Agrarian services were found to be very active in both Vavuniya North and Vavuniya South and that could be used in promoting rubber cultivation in the region.

Income stability appeared to be the principal driving force for farmers to cultivate rubber. Therefore, it has to be advertised in promoting rubber cultivation in this region.

Being mostly surrounded by forests, there is a potential for wild animal damage to rubber cultivation. In any large scale cultivation, this has to be taken into consideration.

This region contributes largely to the food production of the country. To secure the food production whilst providing stable income to the farmers, the concept of "one family one hectare of rubber" is proposed in the expansion process of rubber cultivation.

As an initial target, 4,000 ha of rubber is proposed for Vavuniya district.

Quick way of disbursement of rubber subsidy, effective technology transfer systems and use of machinery for digging holes are proposed for effective expansion of rubber cultivation in this region.

\section{References}

Anon (2012a). Statistical Information 2012, Northern Province. Provincial Planning Secretariat, Northern Province.

Anon (2012b). Department of Census and Statistics, Sri Lanka, Population. District and DS Division level Information (WWW.document) http://www.statistics. gov.lk/. Accessed on November 2012. 
Anon (2010). Statistical Hand Book 2009, Vavuniya. District Planning Secretariat, District Secretariat, Vavuniya.

Anon (2009). Statistical Hand Book 2009, Vavuniya. District Planning Secretariat, District Secretariat, Vavuniya.

Datta, B, Thapaliyal, A P, Ravichandran, S, Singh, M and Nair, N U (2010). Good agricultural practices for non-traditional natural rubber growing areas experiencing extreme agro climatic conditions. IRRDB Workshop on Climate Change and Rubber Cultivation. July 28-30, 2010 Rubber Research Institute of India, Kottayam, India.

Iqbal, S M M, Rodrigo, V H L and Karunathilake, P KW (2010). Feasibility of rubber (Hevea brasiliensis Muell. Arg.) cultivation in Eastern province of Sri Lanka with the peasant community. Journal of the Rubber Research Institute of Sri Lanka 90, 18-30.

Rodrigo, V H L, Iqbal, S M M and Dharmakeerthi, R S (2011a). Potential for rubber (Hevea brasiliensis Muell. Arg.) cultivation in the Eastern province of Sri Lanka. Journal of the National Science Foundation of Sri Lank, 39(4), 403-411.

Rodrigo, V H L, Iqbal, S M M and Seneviratne, W M G (2011b). Rubber Cultivation in the Northern Region of Sri Lanka: Present status and Interim Recommendations. The report presented to the Miniter of Plantation Industires, November 2011, Rubber Research Institute of Sri Lanka. Pp. 13.

Rodrigo, V H L, Iqbal, S M M and Munasinghe, E S (2009). Rural livelihood and rubber cultivation in Eastern province of Sri Lanka. Journal of the Rubber Research Institute of Sri Lanka 89, 58-69.

Address for correspondence: $\mathrm{Dr} \mathrm{V} \mathrm{H} \mathrm{L}$ Rodrigo, Head, Biochemistry and Physiology Dept., Rubber Research Institute of Sri Lanka, Dartonfield, Agalawatta, Sri Lanka.

e-mail: laksh@sltnet.lk 